\title{
Effect of Phosphorus Levels through Integrated Nutrient Management (INM) Packages on Nutrient Content in Various Parts of the Crop
}

\author{
Badka Amruth*, G.N. Thippeshapppa, K.T. Gurumurthy and \\ H.M. Chidanandappa
}
Department of Soil Science and Agricultural Chemistry, University of agricultural and horticultural sciences, Shivamogga, Karnataka, India

*Corresponding author

\begin{abstract}
A B S T R A C T
Keywords

INM, Kharif PSB, Phosphorus

Article Info

Accepted:

16 February 2018

Available Online:

10 March 2018

A field experiment was conducted to investigate the effect of phosphorus levels through integrated nutrient management (INM) packages on nutrient content during the kharif2015-16 under rainfed condition at College of Agriculture, University of Agricultural and Horticultural Sciences, Shivamogga, Karnataka,. The results showed that highest content of $\mathrm{N}$ haulm, shell and kernel $(2.20,1.28$, and $3.43 \%) \mathrm{P}(0.22,0.19,0.43$ $\%) \mathrm{K}(1.25,1.07,1.21 \%), \mathrm{Ca}(1.84,2.19,3.42 \%) \mathrm{Mg}(0.81,1.19,1.91 \%)$ and $\mathrm{S}(0.23$, $0.08,0.22 \%)$ in different parts of groundnut, respectively was recorded in $\mathrm{T}_{6}(75 \%$ of 30 $\mathrm{kg} \mathrm{P}_{2} \mathrm{O}_{5} \mathrm{ha}^{-1}$ through $\mathrm{CF}+25 \%$ through FYM + PSB) whereas lowest value recorded in $\mathrm{T}_{1}$ $\left(20 \mathrm{~kg} \mathrm{P}_{2} \mathrm{O}_{5} \mathrm{ha}^{-1}\right)$ as $\mathrm{N}(1.23,0.67,2.72 \%), \mathrm{P}(0.14,0.13,0.21 \%), \mathrm{K}(1.09,0.85,0.70 \%)$, $\mathrm{Ca}(1.16,1.47,2.23 \%), \mathrm{Mg}(0.52,0.77,1.08 \%), \mathrm{S}(0.13,0.06,0.16 \%)$ compared to rest of treatments. Highest $\mathrm{N}, \mathrm{P}, \mathrm{Ca}, \mathrm{Mg}$ content $(3.43,0.43,0.81,1.91 \%)$ respectively in kernel whereas, highest content of $\mathrm{K}$ and $\mathrm{S}$ content $(1.25$ and $0.23 \%)$ in haulm compared to rest of the parts.
\end{abstract}

\section{Introduction}

Groundnut is also known as peanut (Arachis hypogaea L.) belongs to family of Fabaceae, it is considered as one of the most important oil seed crop and dominant annual crop widely cultivated in India (Rathore and Kamble, 2008). India ranks second in the world in groundnut production with a total sowing area during kharif season have been estimated to be 136,000 hectares in 2015-16. In India, Gujarat has the largest groundnutproducing state followed by Andhra Pradesh and Telangana. Groundnut being an important oilseed crop of the Karnataka, growing in an area of 7.25 Lakh hectares with the production of 6.58 Lakhs tonnes and productivity of $908 \mathrm{~kg} \mathrm{ha}^{-1}$ during 2013-14. The major groundnut growing districts in Karnataka are Chitradurga, Dharwad, Belgaum, Bijapur, Raichur, Bellary and Bidar (Anon., 2015).

Phosphorus play a major role in plant as constituent of nucleoproteins, phytins and phospholipids, essential constituent of number 
of enzymes, important in energy transfer, essential for cell division and development, mainly it aids in nodule formation. It stimulates the setting of pods and hastens the maturity of the crop. Phosphorus stimulates root formulation, growth and increases nitrogen fixation; mainly it aids in nodule formation and increases the protein and mineral content in groundnut kernel. Nowadays, use of chemical fertilizers is increasing to boost up crop production to meet the need for increasing population of the nation. Simultaneously cost of chemical fertilizer has been increasing constantly, besides these; excessive use of inorganic fertilizers alone is injurious to soil health and soil productivity. In soils, applied phosphate fertilizer enter into complex reactions with the various constituents of soils such as $\mathrm{Fe}, \mathrm{Al}$, $\mathrm{Ca}, \mathrm{Mg}$ and get quickly converted to less soluble or insoluble forms as a result 20-25 percent of applied phosphatic fertilizer is utilized by the crop in a season indicating low phosphorus use efficiency and build-up of $\mathrm{P}$ in soil is very common in the soils. The fixation of $\mathrm{P}$ is a $\mathrm{pH}$ dependent chemical reaction that makes it unavailable to crops.

The crops cannot absorb insoluble forms of phosphorous and has to be converted into soluble forms by phosphatase enzyme such as acidic and alkaline phosphatase. Several soil microorganisms like bacteria particularly those belonging to phosphate solubilising bacteria (phosphobacteria) possess the ability to solubilise insoluble inorganic phosphate and make it available to plants.

The solubilization effect is generally due to the production of organic acids by these organisms for instance carbonic acid, has an indirect but definite effect on the nodulation and yield of legume crops like groundnut through increased phosphate solubilization. Incorporation of organic residues into soil influences the reactions of phosphates and its availability to plants, there by increases the $\mathrm{P}$ concentration in soil solution through mineralization of organic $\mathrm{P}$ and solubilisation of native soil $\mathrm{P}$ compounds. During decomposition of organic matter various organic acids are produced which solubilise the phosphates and other $\mathrm{P}$ bearing minerals and thereby lower the P-fixation.

Combined use of organic and chemical and bio fertilizers enhances crop production and sustains soil fertility (Gupta et al., 2003). Integrated use of phosphorus fertilizers with FYM and bio-fertilizers like $\mathrm{P}$ solubilising bacteria for instance Pseudomonas striatus, enhancing the more $\mathrm{P}$ solubility and availability in soils. The INM practices increases available nutrients, facilitates slow release of nutrients and thus reduces nutrient losses. These positive effects enhance nutrient uptake of plants that results in higher productivity. Owing to the ever increasing cost of inorganic chemical fertilizers, the integration of inorganic fertilizers with organic manures and crop residues has become imperative for sustained crop production and maintenance of soil health (Babulkar, 2000).

Phosphorus has been the subject to intensive research because of its peculiar behaviour in soil. As such, $\mathrm{P}$ status is not poor in soils but its availability to plants from soil is meager as it is present mostly in unavailable or fixed forms. Therefore, efforts need to be made to solubilize unavailable $\mathrm{P}$ forms to plant available forms.

Keeping these views and facts in mind, a field experiment was conducted at College of Agriculture, Shivamogga during 2015-2016 on sandy loam soil to study the effect of phosphorus levels through integrated nutrient management (INM) packages on productivity of groundnut (Arachis hypogaea L.) and status of phosphorus in soil with the following 
objective; Effect of phosphorus levels through integrated nutrient management (INM) packages on soil properties and economics of the crop. Effect of phosphorus levels through integrated nutrient management (INM) packages on nutrient content in various parts of the crop.

\section{Materials and Methods}

A field experiment was conducted to investigate the effect of phosphorus levels through integrated nutrient management (INM) packages on productivity of groundnut and status of phosphorus in soil during the kharif2015-16 under rainfed condition at College of Agriculture, University of Agricultural and Horticultural Sciences, Shivamogga and belongs to Southern Transition Agro-climatic Zone of Karnataka (Zone No. 7).

The experimental site is situated at $14^{\circ} 0^{\prime}$ to $14^{\circ} 1^{\prime}$ North latitude and $75^{\circ} 40^{\prime}$ to $75^{\circ} 42^{\prime}$ East longitude with an altitude of 650 meters above the mean sea level. A field experiment was conducted during kharif season of 201516 at College of Agriculture and ZAHRS, Navile, Shivamogga. The experiment comprised nine treatment combinations with three phosphorus levels viz., 20, 30 and $50 \mathrm{~kg}$ $\mathrm{P}_{2} \mathrm{O}_{5}$ ha $^{-1}$ applied through inorganic $\mathrm{P}$ fertilizer (75\%) and FYM (25\%) along with PSB bio fertilizer which are laid out in Randomized Completely Block Design (RCBD) with three replications. The treatment details are $\mathrm{T}_{1}$ : $\mathrm{RDNK}+20 \mathrm{~kg} \mathrm{P}_{2} \mathrm{O}_{5} \mathrm{ha}^{-1}, \mathrm{~T}_{2}: \mathrm{RDNK}+75 \%$ of $20 \mathrm{~kg} \mathrm{P}_{2} \mathrm{O}_{5}$ ha $^{-1}$ through chemical fertilizers (CF) $+25 \%$ through FYM, $\mathrm{T}_{3}: \mathrm{T}_{2}+\mathrm{PSB}, \mathrm{T}_{4}$ : $\mathrm{RDNK}+30 \mathrm{~kg} \mathrm{P}_{2} \mathrm{O}_{5} \mathrm{ha}^{-1}, \mathrm{~T}_{5}: \mathrm{RDNK}+75 \%$ of $30 \mathrm{~kg} \mathrm{P}_{2} \mathrm{O}_{5} \mathrm{ha}^{-1}$ through chemical fertilizers (CF) $+25 \%$ through FYM T 6 : $\mathrm{T}_{5}+\mathrm{PSB}, \mathrm{T}_{7}$ : $\mathrm{RDNK}+50 \mathrm{~kg} \mathrm{P}_{2} \mathrm{O}_{5} \mathrm{ha}^{-1}, \mathrm{~T}_{8}: \mathrm{RDNK}+75 \%$ of $50 \mathrm{~kg} \mathrm{P}_{2} \mathrm{O}_{5}$ ha $^{-1}$ through chemical fertilizers (CF) $+25 \%$ through FYM and $\mathrm{T}_{9}: \mathrm{T}_{8}+$ PSB . Soil texture (Piper, 1966), soil pH and EC determined by standard procedures laid out by Jackson (1973). Total nitrogen phosphorus, potassium, calcium Jackson (1973) while, total sulphur laid out by Black (1965). Fisher's method of analysis of variance was used for analysis and interpretation of the data as outlined by Panse and Sukhatme (1985).

\section{Results and Discussion}

The results obtained from the present investigation as well as relevant discussion have been summarized under following heads;

\section{Primary nutrients content of groundnut plant parts}

Effects of phosphorus levels through INM packages on nitrogen, phosphorus and potassium content in haulm, shell and kernel of groundnut given in Table 1 .

At harvest, the significantly higher nitrogen content in haulm, shell and kernel of groundnut was recorded due to application of $75 \%$ of $30 \mathrm{~kg} \mathrm{P}_{2} \mathrm{O}_{5} \mathrm{ha}^{-1}$ through $\mathrm{CF}+25 \%$ through FYM + PSB $\left(\mathrm{T}_{6}\right)(2.20,1.28$ and 3.43 $\%$, respectively) followed by $\mathrm{T}_{9}$ treatment and compare to other treatments. Whereas, significantly lower nitrogen content of haulm was recorded in treatment $\mathrm{T}_{1}(1.23,0.67$ and $2.72 \%$, respectively) supplied with $20 \mathrm{~kg}$ $\mathrm{P}_{2} \mathrm{O}_{5}$ ha $^{-1}$.

The symbiotic nitrogen fixation is known to decline after flowering and nitrogen concentration in haulm parts decreases during pod development stage and at harvest stage. This might also be due to $\mathrm{P}$ fertilization which helps in promoting root growth efficient functions of nodule bacteria. Thus expanded root system increased the number and dry weight of nodules. Similar trend was noticed with respect to $\mathrm{N}$ concentration Bheemaiah and Ananthanarayana (1984), Ranjith, (2007), 
Grimme (1977) and Loganathan and Krishnamurthy (1977).

It was observed from the results that the content of phosphorus of haulm, shell and kernel as influenced by different $\mathrm{P}$ levels applied through INM packages are presented in Table 1. The treatment supplied with $75 \%$ of $30 \mathrm{~kg} \mathrm{P}_{2} \mathrm{O}_{5} \mathrm{ha}^{-1}$ through $\mathrm{CF}+25 \%$ through FYM + PSB $\left(T_{6}\right)$ was recorded higher phosphorus content in haulm, shell and kernel $(0.22,0.19$ and $0.43 \%$, respectively) followed by treatment $\mathrm{T}_{9}$. It was statistically on par with application of $75 \%$ of $50 \mathrm{~kg} \mathrm{P}_{2} \mathrm{O}_{5} \mathrm{ha}^{-1}$ through CF $+25 \%$ through FYM + PSB $\left(\mathrm{T}_{9}\right)$. The lower phosphorus content $(0.14,0.13$ and $0.21 \%$, respectively) was recorded in $\mathrm{T}_{1}(20$ kg $\left.\mathrm{P}_{2} \mathrm{O}_{5} \mathrm{ha}^{-1}\right)$.

The increase in $\mathrm{P}$ content in plant parts by integrated use of $\mathrm{P}$ fertilizers thereby increases the $\mathrm{P}$ availability in soil solution, besides increases the absorption of $\mathrm{P}$ by roots. The FYM and PSB helps in mobilization and mineralization of phosphorus in soil. Similar results were confirmed by Loganathan and Krishnamurthy (1977), Bajrang et al., (2013), Bagayoko et al., (2000), Rebafka et al., (1993) and Singh and Pareek (2003).

The results obtained on the content of potassium in haulm, shell and kernel as influenced by various treatments (Table 1) effects, the results were found to be significant. Application of $75 \%$ of $30 \mathrm{~kg}$ $\mathrm{P}_{2} \mathrm{O}_{5} \mathrm{ha}^{-1}$ through $\mathrm{CF}+25 \%$ through FYM + PSB in treatment $\mathrm{T}_{6}$ was recorded maximum potassium content in haulm, shell and kernel $(1.25,1.07$ and $1.21 \%$, respectively).

But it was on statistically par with treatment $\mathrm{T}_{9}\left(75 \%\right.$ of $50 \mathrm{~kg} \mathrm{P}_{2} \mathrm{O}_{5} \mathrm{ha}^{-1}$ through $\mathrm{CF}+25$ $\%$ through FYM + PSB). Significantly lower potassium content $(1.09,0.85$ and $0.70 \%$, respectively) was recorded in treatment $\mathrm{T}_{1}(20$ $\mathrm{kg} \mathrm{P}_{2} \mathrm{O}_{5} \mathrm{ha}^{-1}$ ).
Increased concentration of $\mathrm{K}$ might be due to application of $\mathrm{N}$ and $\mathrm{P}$ which increased the potassium content in plant significantly. The haulm parts contained higher potassium content, indicating that importance of potassium for proper vegetative growth. These results were similar with findings of Basu (2010), Bagayoko (2000), Rebafka et al., (1993) and Mahalnobis and Matti (1999) in groundnut.

\section{Secondary nutrients content of groundnut plant parts}

The data pertaining to $\mathrm{Ca}, \mathrm{Mg}$ and Scontentof haulm, shell and kernel as influenced by various treatments are presented in Table 2 .

Significantly higher calcium content in haulm, shell and kernel was obtained in treatment $\mathrm{T}_{6}$ applied with $75 \%$ of $30 \mathrm{~kg} \mathrm{P}_{2} \mathrm{O}_{5}$ ha $^{-1}$ through CF $+25 \%$ through FYM + PSB $(1.84,2.19$ and $3.42 \%$, respectively) followed by $\mathrm{T}_{9}$ treatment. Application of $20 \mathrm{~kg} \mathrm{P}_{2} \mathrm{O}_{5}$ ha $^{-1}$ had shown significantly lower calcium content (1.16, 1.47 and $2.23 \%$, respectively). Groundnut crop is a heavy feeder of calcium, it responds well with the increase of calcium in solution. Solution concentration of calcium was enhanced appreciably with the addition of lime combined with the Phosphate fertilizers. The results are in conformity with the finding of Haynes (1992) and Bagayoko et al., (2000).

Significant increase of magnesium content in haulm, shell and kernel $(0.23 \%)$ was recorded when supplied with $75 \%$ of $30 \mathrm{~kg}$ $\mathrm{P}_{2} \mathrm{O}_{5}$ ha $^{-1}$ through $\mathrm{CF}+25 \%$ through FYM + PSB due to $\mathrm{T}_{6}(0.81,1.19$ and $1.91 \%$, respectively) followed by $\mathrm{T}_{9}$ treatment. Whereas, significantly lower magnesium $(0.52$, and 0.77 and $1.08 \%$, respectively) content was registered in haulm, shell and kernel when supplied with low dose of P @ $20 \mathrm{~kg} \mathrm{P}_{2} \mathrm{O}_{5} \mathrm{ha}^{-1}\left(\mathrm{~T}_{1}\right)$. 
Table.1 Effect of phosphorus levels through integrated nutrient management (INM) packages on NPK content of groundnut plant parts at harvest of groundnut

\begin{tabular}{|c|c|c|c|c|c|c|c|c|c|}
\hline \multirow[t]{2}{*}{ Treatments } & \multicolumn{3}{|c|}{$N(\%)$} & \multicolumn{3}{|c|}{$P(\%)$} & \multicolumn{3}{|c|}{$K(\%)$} \\
\hline & Haulm & Shell & Kernel & Haulm & Shell & Kernel & Haulm & Shell & Kernel \\
\hline$T_{1}: 20 \mathrm{~kg} \mathrm{P}_{2} \mathrm{O}_{5} \mathrm{ha}^{-1}$ & 1.23 & 0.67 & 2.72 & 0.14 & 0.13 & 0.21 & 1.09 & 0.85 & 0.70 \\
\hline $\mathrm{T}_{2}: 75 \%$ of $20 \mathrm{~kg} \mathrm{P}_{2} \mathrm{O}_{5} \mathrm{ha}^{-1}$ through $\mathrm{CF}+25 \%$ through $\mathrm{FYM}$ & 1.45 & 0.75 & 2.89 & 0.15 & 0.14 & 0.24 & 1.14 & 0.87 & 0.80 \\
\hline$T_{3}: T_{2}+P S B$ & 1.62 & 0.82 & 3.04 & 0.16 & 0.15 & 0.26 & 1.17 & 0.90 & 0.90 \\
\hline$T_{4}: 30 \mathrm{~kg} \mathrm{P}_{2} \mathrm{O}_{5} \mathrm{ha}^{-1}$ & 1.78 & 0.85 & 3.11 & 0.17 & 0.16 & 0.34 & 1.19 & 0.96 & 1.04 \\
\hline$T_{5}: 75 \%$ of $30 \mathrm{~kg} \mathrm{P}_{2} \mathrm{O}_{5} \mathrm{ha}^{-1}$ through $\mathrm{CF}+25 \%$ through FYM & 1.89 & 1.12 & 3.27 & 0.18 & 0.17 & 0.39 & 1.21 & 1.01 & 1.11 \\
\hline$T_{6}: T_{5}+P S B$ & 2.20 & 1.28 & 3.43 & 0.22 & 0.19 & 0.43 & 1.25 & 1.07 & 1.21 \\
\hline$T_{7}: 50 \mathrm{~kg} \mathrm{P}_{2} \mathrm{O}_{5} \mathrm{ha}^{-1}$ & 1.99 & 1.14 & 3.29 & 0.19 & 0.18 & 0.41 & 1.22 & 1.04 & 1.08 \\
\hline$T_{8}: 75 \%$ of $50 \mathrm{~kg} P_{2} \mathrm{O}_{5} h^{-1}$ through $\mathrm{CF}+25 \%$ through FYM & 2.03 & 1.19 & 3.34 & 0.19 & 0.19 & 0.42 & 1.23 & 1.05 & 1.12 \\
\hline$T_{9}: T_{8}+P S B$ & 2.08 & 1.23 & 3.41 & 0.20 & 0.19 & 0.42 & 1.24 & 1.06 & 1.16 \\
\hline S Em \pm & 0.058 & 0.042 & 0.067 & 0.007 & 0.005 & 0.056 & 0.026 & 0.036 & 0.022 \\
\hline $\mathrm{CD}(\mathrm{P}=0.05)$ & 0.17 & 0.12 & 0.20 & 0.022 & 0.016 & 0.18 & 0.070 & 0.108 & 0.067 \\
\hline
\end{tabular}


Table.2 Effect of phosphorus levels through integrated nutrient management (INM) packages on Ca, $\mathrm{Mg}$ and $\mathrm{S}$ content of groundnut plant parts at harvest of groundnut

\begin{tabular}{|c|c|c|c|c|c|c|c|c|c|}
\hline \multirow[t]{2}{*}{ Treatments } & \multicolumn{3}{|c|}{$\mathrm{Ca}(\%)$} & \multicolumn{3}{|c|}{$M g(\%)$} & \multicolumn{3}{|c|}{$S(\%)$} \\
\hline & Haulm & Shell & Kernel & Haulm & Shell & Kernel & Haulm & Shell & Kernel \\
\hline$T_{1}: 20 \mathrm{~kg} P_{2} \mathrm{O}_{5} h a^{-1}$ & 1.16 & 1.47 & 2.23 & 0.52 & 0.77 & 1.08 & 0.13 & 0.06 & 0.16 \\
\hline$T_{2}: 75 \%$ of $20 \mathrm{~kg} \mathrm{P}_{2} \mathrm{O}_{5} \mathrm{ha}^{-1}$ through $\mathrm{CF}+25 \%$ through $\mathrm{FYM}$ & 1.31 & 1.59 & 2.36 & 0.58 & 0.83 & 1.19 & 0.14 & 0.06 & 0.18 \\
\hline$T_{3}: T_{2}+P S B$ & 1.53 & 1.69 & 2.53 & 0.62 & 0.86 & 1.33 & 0.15 & 0.06 & 0.18 \\
\hline$T_{4}: 30 \mathrm{~kg} \mathrm{P}_{2} \mathrm{O}_{5} h a^{-1}$ & 1.61 & 1.76 & 2.81 & 0.69 & 0.90 & 1.67 & 0.16 & 0.06 & 0.18 \\
\hline$T_{5}: 75 \%$ of $30 \mathrm{~kg} \mathrm{P}_{2} \mathrm{O}_{5} \mathrm{ha}^{-1}$ through $\mathrm{CF}+25 \%$ through $\mathrm{FYM}$ & 1.72 & 1.89 & 3.12 & 0.74 & 0.96 & 1.78 & 0.18 & 0.07 & 0.19 \\
\hline$T_{6}: T_{5}+P S B$ & 1.84 & 2.19 & 3.42 & 0.81 & 1.19 & 1.91 & 0.23 & 0.08 & 0.22 \\
\hline$T_{7}: 50 \mathrm{~kg} \mathrm{P}_{2} \mathrm{O}_{5} \mathrm{ha}^{-1}$ & 1.74 & 2.02 & 2.96 & 0.75 & 1.00 & 1.87 & 0.19 & 0.07 & 0.21 \\
\hline$T_{8}: 75 \%$ of $50 \mathrm{~kg} \mathrm{P}_{2} \mathrm{O}_{5}$ ha $^{-1}$ through $\mathrm{CF}+25 \%$ through FYM & 1.75 & 2.07 & 3.13 & 0.76 & 1.09 & 1.87 & 0.20 & 0.07 & 0.21 \\
\hline$T 9: T_{8}+P S B$ & 1.77 & 2.13 & 3.17 & 0.78 & 1.13 & 1.88 & 0.20 & 0.07 & 0.22 \\
\hline S Em \pm & 0.19 & 0.047 & 0.08 & 0.02 & 0.048 & 0.067 & 0.008 & 0.005 & 0.006 \\
\hline $\mathrm{CD}(\mathrm{P}=\mathbf{0 . 0 5})$ & 0.57 & 0.14 & 0.24 & 0.06 & 0.14 & 0.20 & 0.024 & 0.015 & 0.018 \\
\hline
\end{tabular}

CF: Chemical Fertilizers, PSB: Phosphorus Solubilising Bacteria. 
Similarly, sulphur content of haulm, shell and kernel also significantly increased $(0.23,0.08$ and $0.22 \%$, respectively) due to treatment supplied with $75 \%$ of $30 \mathrm{~kg} \mathrm{P}_{2} \mathrm{O}_{5} \mathrm{ha}^{-1}$ through $\mathrm{CF}+25 \%$ through FYM + PSB $\left(\mathrm{T}_{6}\right)$ followed by $\mathrm{T}_{9}$ treatment. Whereas, significantly lower sulphur content $(0.13,0.06$ and $0.16 \%$, respectively) was recorded due to treatment $\mathrm{T}_{1}$ supplied $20 \mathrm{~kg} \mathrm{P}_{2} \mathrm{O}_{5} \mathrm{ha}^{-1}$ without FYM and PSB. The positive influence of gypsum fertilization owing to be the results of improved nutritional environment in the rhizosphere as well as in the plant system which leads to translocation of $\mathrm{P}$ and $\mathrm{S}$ to productive parts which ultimately increased the concentration of $\mathrm{P}$ and $\mathrm{S}$ in plant parts. The $S$ was high in kernel where it was involved in $\mathrm{S}$ containing amino acids, proteins and oil synthesis. Similar results were reported by Rao and Shaktawat (2005), Kishore Babu et al., (2007) and Bajrang et al., (2013).

In conclusion, results revealed that by adoption of integrated phosphorus application with FYM and phosphorus solubilizing bacteria significantly enhanced the nutrient availability and uptake by mechanism of solubilisation. Application of $75 \%$ of $30 \mathrm{~kg}$ $\mathrm{P}_{2} \mathrm{O}_{5}$ ha $^{-1}$ through CF $+25 \%$ through FYM + PSB increased the nutrient content in plant parts compared to rest of the other treatment. It could be concluded that 30 level phosphorus was superior to rest of levels.

\section{References}

Anonymous, 2015, Area, production and productivity of groundnut in India. India stat.com.

Babulkar P S, Wandile R M,Badole W P and Balpande S S, 2000, Residual effect of long term application of FYM and fertilizers on soil properties and yield of soybean. J. Indian Soc. Soil Sci., 48(1): 89-92.
Bagayoko M., George, V., Romheld V. And Buerkert, A., 2000, Effects of mycorrhizae and phosphorus on growth and nutrient uptake of millet, cowpea and sorghum on a West African soil. J. Agric. Sci., 135(04): 399-407.

Bajrang LO., Pareek, BL., Yadav RS., Shivran A. C. And Sharma OP., 2013, Influence of integrated nutrient management on productivity and quality of groundnut in Western Rajasthan. Ann. Agric. Res. New Series, 34(2): 156-159.

Basu TK., 2011, Effect of cobalt, rhizobium and phosphobacterium inoculations on growth, yield, quality and nutrient uptake of summer groundnut (Arachis hypogaea L,). American J. Exper. Agri., 1(1): 21-26.

Bheemaiah KA. andAnanthanarayana R., 1984, Nutrition of groundnut in relation to calcium interaction of soil. J. Indian Soc. Soil Sci., 32: 766-776.

Black CA., 1965, Methods of Soil Analysis, Part II, Chemical and microbiological properties, No. 9 series, Agronomy, Am. Soc. Agron., Madison, Wisconsin, USA.

Grimme H., 1977, Potassium, calcium and magnesium interaction in relation to uptake and yield. Natural Resource Develop., 5: 84-94.

Gupta R K, Kaushik S, Sharma P and Jain VK., 2003, Biofertilizers: An ecofriendly alternative to chemical fertilizers. Environmental Challenges of the $21^{\text {st }}$ Century, APH Publishing Corporation, New Delhi, pp. 275-287.

Haynes R J, 1992, Effects of liming on phosphate availability in acid soils. $P l$. Soil,68: 289-308.

Jackson M L., 1973, Soil Chemical Analysis. Prentice Hall Pvt. Ltd., New Delhi.

Kishore Babu, G., Munaswamy, V., John, K. and Padma Raju, A. 2007, Effect of 
applied nutrients on major (NPK) and secondary $(\mathrm{Ca}, \mathrm{Mg}, \quad \mathrm{S})$ nutrients concentration at different growth stages of rainfed groundnut, (Arachis hypogaea L.) in alfisols. J. Oilseeds Res., 24(1): 84-87.

Loganathan, S. and Krishnamoorthy, KK., 1977, Total uptake of nutrients at different stages of the growth of groundnut and the ratios in which various nutrient elements exist in groundnut plant. $\mathrm{Pl}$. soil, 46(3): 565570 .

Mahalanobis, D. and Maiti, D., 1998, Dry matter production, nutrient content and uptake by groundnut intercropping at different levels of nitrogen and phosphorus application. J. Oilseeds Res., 16(1): 68-73.

Panse, VG. andSukhatme P V., 1985, Statistical methods for agricultural workers Indian Council of Agricultural Research (IARI), New Delhi. pp. 167-174.

Piper, C. S., 1966, Soil and Plant Analysis, University Adelaide, Australia.

Ranjit R, Dasog G. S. and Patil P. L., 2007, Effect of lime and phosphorus levels on the pod, haulm and oil yield of two groundnut genotypes in acid soils of coastal agro-ecosystem of Karnataka. Karnataka J. Agric. Sci., 20(3): 627630.

Rao SS and Shaktawat MS., 2005, Effect of organic manure, phosphorus and gypsum on nutrient uptake in groundnut. Agropedology, 15(2): 100106.

Rathore, P. K. and Kamble B. M, 2008, integrated nutrient management in summer groundnut. Adv. Plant Sci., 21: 329-331.

Rebafka FP., Ndunguru BJ. andMarschner H., 1993, Single superphosphate depresses molybdenum uptake and limits yield response to phosphorus in groundnut (Arachis hypogaea L.) grown on an acid sandy soil in Niger, West Africa. Fertilizer Res., 34(3): 233-242.

Singh B. And Pareek RG., 2003, Effect of phosphorus and bio-fertilizers on growth and yield of mungbean. Indian J. Pulses Res., 16: 31-33.

\section{How to cite this article:}

Badka Amruth, G.N. Thippeshapppa, K.T. Gurumurthy and Chidanandappa, H.M. 2018. Effect of Phosphorus Levels through Integrated Nutrient Management (INM) Packages on Nutrient Content in Various Parts of the Crop. Int.J.Curr.Microbiol.App.Sci. 7(03): 2080-2087. doi: https://doi.org/10.20546/ijcmas.2018.703.244 